\title{
DESIGN OF HHO GENERATOR TO REDUCE EXHAUST GAS EMISSIONS AND FUEL CONSUMPTION OF NON-INJECTION GASOLINE ENGINE
}

\author{
Harman $^{1}$, Ahyar M. ${ }^{2}$ \\ 1,2 Jurusan Teknik Mesin, Akademi Teknik Soroako, Kab. Luwu Timur, Sulawesi Selatan \\ Email: tosaha@yahoo.com
}

\begin{abstract}
The continuous increase of fuel consumption has caused fossil fuel shortages, rising its price tremendously. Transportation activities have the largest contribution to air pollution in the form of exhaust gas compared to other industrial activities. Various methods have been used to reduce the air pollution level as well as reducing fuel consumptions, one of which is the use of environmentally friendly fuel gas. The fuel gas is obtained from the electrolysis of water into oxy-hydrogen gas (HHO) as additive in fuel combustion process. The research methodology is experimental research which consists of designing and manufacturing of $\mathrm{HHO}$, and field testing. In the planning and manufacturing stages an HHO generator is produced, equipped with an input voltage regulator in order to produce the gas as needed, with shape and size adapted to the available space on the engine room. The testing stage was conducted on a 1781 cc engine, 2015 Toyota pick up truck which included laboratory test and on the road test. The results show that by activating the HHO generator, there is a reduction of $\mathrm{CO}$ and $\mathrm{HC}$ emissions, and also a reduction in fuel consumption, when compared to the operation of the vehicle at the same load but without HHO generator.
\end{abstract}

Keywords: oxy-hydrogen, gasoline engine, exhaust gas emission

\begin{abstract}
ABSTRAK
Meningkatnya konsumsi bahan bakar minyak secara terus menerus menyebabkan kelangkaan ketersediaan bahan fosil di alam, sehingga harganya menjadi mahal. Kegiatan transportasi menyumbangkan polusi udara dari hasil emisi gas buang kendaraan terbesar dibanding kegiatan industri lainnya. Oleh karena itu dilakukan berbagai cara untuk menurunkan tingkat polusi udara sekaligus menurunkan konsumsi bahan bakar minyak. Salah satunya adalah penggunaan gas bakar ramah lingkungan yang diperoleh dari elektrolisis air gas oksihidrogen (HHO) sebagai bahan tambah dalam proses pembakaran bahan bakar. Metodologi penelitian ini adalah penelitian eksperimental yang terdiri atas perancangan dan pembuatan generator HHO serta pengujian lapangan. Pada tahap perancangan dan pembuatan dibuat generator gas HHO yang dilengkapi dengan pengatur tegangan input agar menghasilkan gas sesuai kebutuhan, dengan bentuk dan ukuran yang disesuaikan dengan tempat yang tersedia pada ruang mesin. Sedangkan pengujian dilakukan pada Mobil Toyota Kijang Pick Up 1781cc pembuatan tahun 2005 yang meliputi uji laboratorium dan uji jalan di jalan raya. Hasil yang diperoleh bahwa dengan mengaktifkan generator $\mathrm{HHO}$, terjadi penurunan emisi $\mathrm{CO}$ dan $\mathrm{HC}$ serta penurunan konsumsi bahan bakar pada beban yang sama, dibandingkan jika kendaraan dioperasikan tanpa generator HHO.
\end{abstract}

Kata kunci: oksihidrogen, motor bensin, emisi gas buang

\section{PENDAHULUAN}

Meningkatnya jumlah kepemilikan kendaraan bermotor baik berbahan bakar bensin maupun solar memicu dampak lain dalam hal peningkatan polutan hasil pembakaran bahan bakar kendaraan. Tidak dapat dihindari bahwa gas polutan (CO, HC, NOx) akan selalu ada pada pemakaian kendaraan berbahan bakar fosil
(Nanny dkk., 2008). Untuk mengurangi polusi tersebut maka perbaikan perlu dilakukan pada proses pembakaran kendaraan (Miranti W., 2010; Harman dkk., 2015)

Pada kendaraan sendiri telah banyak menggunakan komponen penunjang guna mengurangi gas polutan tersebut. Selain dengan menggunakan komponen penujang yang umumnya terdapat pada kendaraan yang 
menerapkan ECU (kendaraan EFI), pengurangan juga dapat dilakukan dengan memperbaiki pembakaran kendaraan menggunakan gas hydrogen sebagai bahan tambah pada kendaraan melalui proses elektrolisis air, dimana dengan memisahkan unsur air (H2O) menjadi gas hidrogen yang mudah terbakar dan gas oksigen yang dibutuhkan dalam proses pembakaran hal ini dapat memperbaiki proses pembakaran yang berdampak pada pengurangan gas polutan sisa pembakaran pada kendaraan dengan memanfaatkan kedua gas tersebut (Yilmaz dkk., 2010; Kosar dkk., 2011; Sunyoto, 2011).

Penelitian tentang pemanfaatan air yang diekstraksi untuk dimanfaatkan sebagai alternatif maupun sebagai aditif bahan bakar yang bertujuan untuk menurunkan emisi gas buang kendaraan pun telah dilakukan oleh para peneliti diantaranya: Ajat Sudrajat, salah seorang dosen UNAS-Jakarta telah menemukan alat penghemat kendaraan bermotor bernama EcoPowerBosster (EPB). Dan setelah diuji langsung pada motor bensin (Premium+HHO) ditengarai dapat menurunkan emisi gas buang sebesar 30\% (Sudrajat dkk., 2011). Harman, juga melakukan pengujian laboratorium tentang Pengaruh Penambahan Gas HHO terhadap Unjuk Kerja Motor Bensin Berbahan Bakar Pertamaks dengan menggunakan sel basah, hasilnya bahwa dengan Penambahan gas Oksihidrogen memberikan pengaruh yang positif terhadap kinerja motor bensin yang berbahan bakar Pertamaks. Hal ini dapat meningkatkan daya efektif mesin dan efisiensi thermis, dan menurunkan konsumsi bahan bakar (Harman dkk, 2015).

Dengan memanfaatkan prinsip elektrolisis air, yang mana proses elektrolisis air ini sendiri adalah proses pengurian air $(\mathrm{H} 2 \mathrm{O})$ menjadi gas hidrogen $(\mathrm{H} 2)$ dan gas oksigen (O2), sehingga air dapat digunakan sebagai bahan bakar (Purnomo, 2010; Saipul, 2015). Dengan menggunakan arus listrik dari battrai, dua molekul air bereaksi dengan menangkap 2 elektron pada katoda yang terinduksi menjadi gas (H2) dan ion hidroksida ( $\mathrm{OH}-$ ). Pada kutup anoda, dua molekul air lainya akan terurai menjadai gas oksigen $(\mathrm{O} 2)$ dengan melepas 4 ion $\mathrm{H}+$. Gas hydrogen dan gas oksigen yang dihasilkan oleh reaksi pada katoda dan anoda membentuk gelembung dan mengumpul di sekitar elektroda (Emannuel dkk.; Hasan, 2011, Sunyoto, 2011, Sudrajat dkk., 2011).

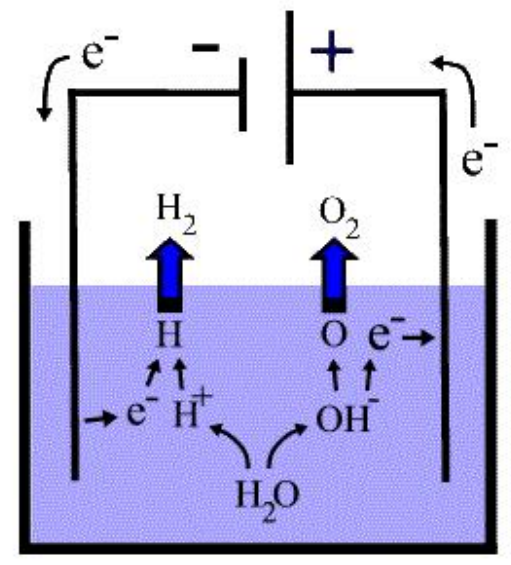

Gambar 1. Proses terbentuknya HHO (Sudrajat, 2011)

Dari hasil reaksi maka akan terbentuk gas oxyhydrogen $(\mathrm{HHO})$ dalam senyawa air $(\mathrm{H} 2 \mathrm{O})$ pada wadah elektrolisis.

\section{Performa Generator HHO}

Energi listrik pada baterai aki dipergunkan untuk sistem kelistrikan di kendaraan (seperti lampu-lampu, sistem pengapian, klakson, dan aksesoris lainnya). Namun masih ada sisa energi listrik yang dapat dipergunakan sebagai sumber tegangan untuk generator oksihidrogen. Energi listrik tersebut jumlahnya terbatas, sehingga generator oksihidrogen yang dipasang pada kendaraan dayanya harus dibatasi. Oleh karena itu harus diketahui seberapa besar daya yang dibutuhkan oleh generator Oksihidrogen. Perumusan untuk mencari daya yang dibutuhkan adalah sebagai berikut:

$P=\frac{E^{2}}{R}$

Diketahui bahwa $\mathrm{P}$ adalah daya yang dibutuhkan (watt), E adalah tegangan (volt) dari 
baterai dan $\mathrm{R}$ adalah nilai tahanan yang dibutuhkan (Ohm) (Harman dkk., 2015).

Untuk mengetahui volume gas oksihidrogen yang dihasilkan, diukur dengan menggunakan flowmeter yang dapat diperoleh dengan persamaan:

$\mathrm{V}=30 / \mathrm{t}$

Dimana V adalah laju Produksi gas HHO (ml), 30 adalah jumlah yang dihasilkan diukur dengan flowmeter dan $t$ adalah waktu yang diperlukan untuk menghasilkan gas oksihidrogen (Purnomo, 2010)

Produk gas Oksihidrogen yang terukur pada Oksihidrogen flowmeter dalam satuan 1/min, dan energi yang berikan untuk memproduksi gas Oksihidrogen adalah energi listrik yang dibutuhkan untuk terjadinya reaksi elektrolisis air dalam satuan watt $(\mathrm{J} / \mathrm{sec})$. Maka untuk menghiting peforma generator Oksihidrogen diturunkan dari persamaan berikut ini:

$\operatorname{Cop}_{\text {IIILO }}=\frac{\text { Energi yang digusilkan nleh generator }}{\text { Daya yaing dibutuhkan }} \times 100 \%$

$C O P_{H H O}=\frac{m_{H H O} \times L H V}{p_{H H O}} \times 100 \%$

Dimana COP adalah performa generator oksihidrogen (\%), $\mathrm{m}$ adalah laju aliran massa gas oksihidrogen (1/min), LHV adalah nilai kalor bawah $(\mathrm{kJ} / \mathrm{kg})$ dan $\mathrm{P}$ adalah daya yang dibutuhkan generator (watt) (Purnomo, 2010)

\section{METODE}

Bahan yang diperlukan dalam pembuatan generator dan tabung perangkap gas HHO ialah resin fiber yang dicetak dengan campuran katalis (cairan pengeras) dengan $3 \mathrm{ml}$ resin dicampur dengan $1 \mathrm{ml}$ katalis (cairan pengeras). Sedangkan untuk elektroda terdiri dari plate stainless steel yang dibentuk sesuai dengan kontur tabung diikat pada batang ulir stainless steel yang dilapisi teflon dengan pemisah dari ring gasket agar elektroda tidak saling kontak.

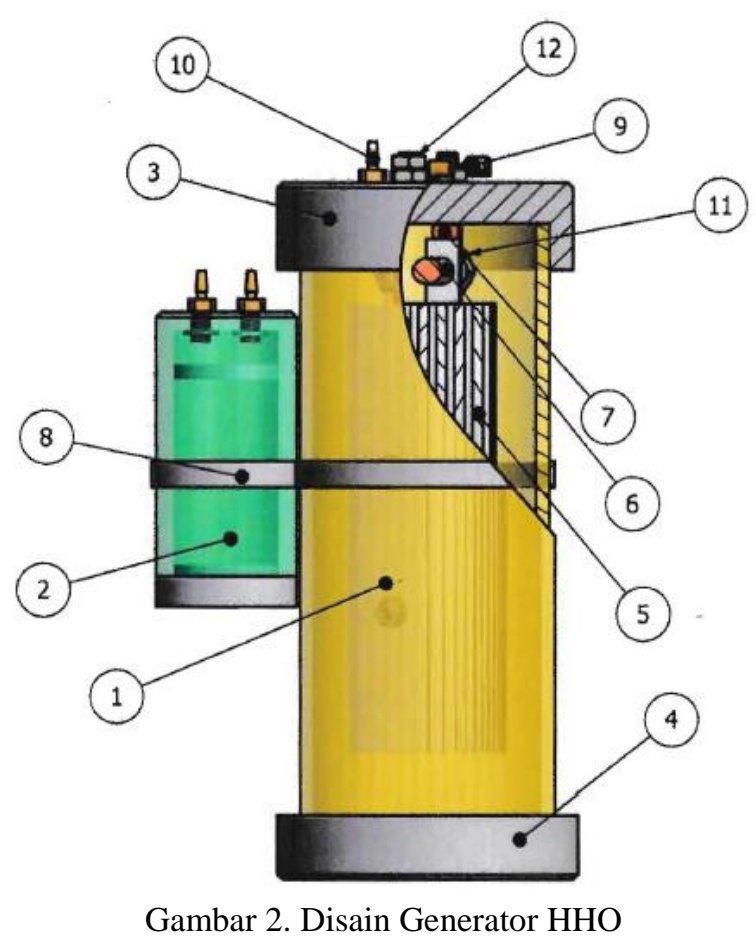

Keterangan

1. Tabung pembangkit gas

2. Perangkap gas

3. Tutup atas

4. Tutup Bawah

5. Sel elektroda

6. Batang pengikat sel

7. Penghantar arus

8. Bracket

9. Lubang pemasukan air

10. Konektor selang gas

11. Mur pegikat

12. Baut penghubung kabel

Sistem pengatur arus menggunakan resistor daya yang dirangkai secara seri dan paralel, dan dilengkapi dengan digital amp-volmeter. untuk mengetahui konsumsi daya dari generator. 


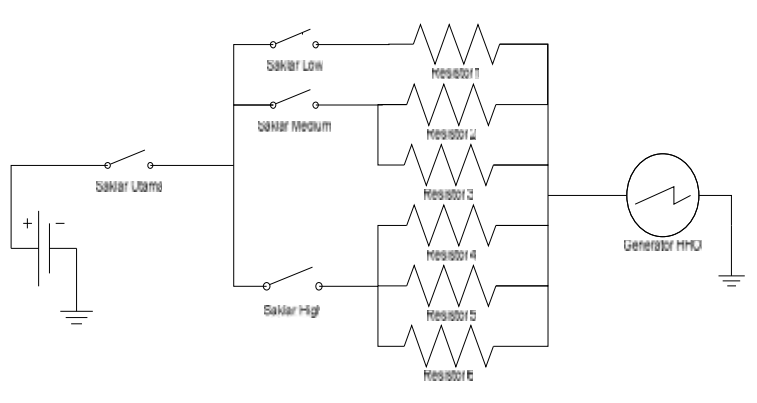

Gambar 3. Skema Rangkaian Pengatur Daya suplai generator

Untuk bahan baku pengurai gas $\mathrm{HHO}$ yaitu menggunakan katalis bubuk $\mathrm{NaOH}$ dicampur dengan air destilasi dengan perbandingan campuran $2 \%$ yakni $2 \mathrm{mg}$ bubuk $\mathrm{NaOH}$ dan 1 liter air destilasi. Alat-alat yang digunakan dalam pembuatan generator adalah, mesin-mesin manufaktur (Turning, Milling, Bor) serta perkakas tangan. Media uji kinerja menggunakan Mobil Toyota Kijang Pick Up 1781cc pembuatan tahun 2005 berbahan bakar Premium. Sedangkan emisi gas buang diukur menggunakan Emision Gas Analyzer QROTECH model QRO-401.

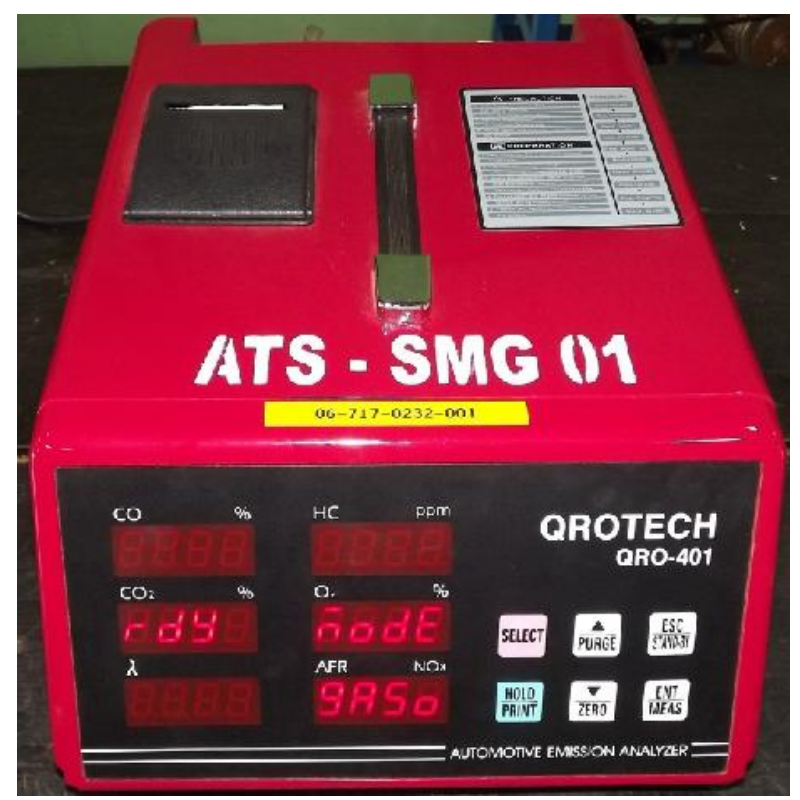

Gambar 4. Emission gas analyzer
Prosedur penelitian ini, mula-mula dilakukan perencanaan Generator Oksihidrogen untuk menghasilkan gas HHO. Dimensi maksimal ditentukan sesuai dengan tempat yang tersedia pada ruang mesin. Pengujian pertama dilakukan dengan menguji kinerja generator secara langsung dengan mengukur konsumsi daya. Karena daya yang tersedia pada kendaraan untuk kebutuhan aksesoris tambahan, maka diperlukan selektor untuk mengatur supply daya ke generator. Sehingga langkah berikutnya adalah merancang selektor daya dengan 4 pilihan termasuk supply langsung. Pengujian kedua dilakukan dengan menguji kinerja generator dengan tambahan selektor daya. Pengujian ketiga adalah uji kinerja dengan memasang generator pada tempat yang direncanakan untuk Mobil Toyota Kijang Pick Up 1781cc (Gambar 7). Selektor daya diletakkan pada ruang kemudi agar dapat dijangkau oleh pengemudi saat diperlukan supply gas HHO. Pada pengujian ini tangki bahan bakar mobil dilakukan modifikasi agar dapat dilakukan pengukuran penggunaan bahan bakar bensin secara teratur. Medan yang dilalui sesuai dengan kondisi jalan sebenarnya di sekitar wilayah Sorowako, Kab. Luwu Timur, Propinsi Sulawesi selatan. Terdapat jalur perbukitan dan jalan rata seperti perkotaan pada umumnya. Pengujian ini juga merupakan rangkaian pengukuran emisi gas buang kendaraan, namun dengan cara, kendaraan diangkat kemudian dioperasikan pada putaran $2500 \mathrm{rpm}$ (Gambar 9). Terdapat mekanisme penahan roda agar torsi mesin menjadi besar. Pengukuran dilakukan, baik dengan tambahan gas HHO maupun tanpa gas HHO. Diagram alir pengujian tahap ketiga seperti dibawah: 


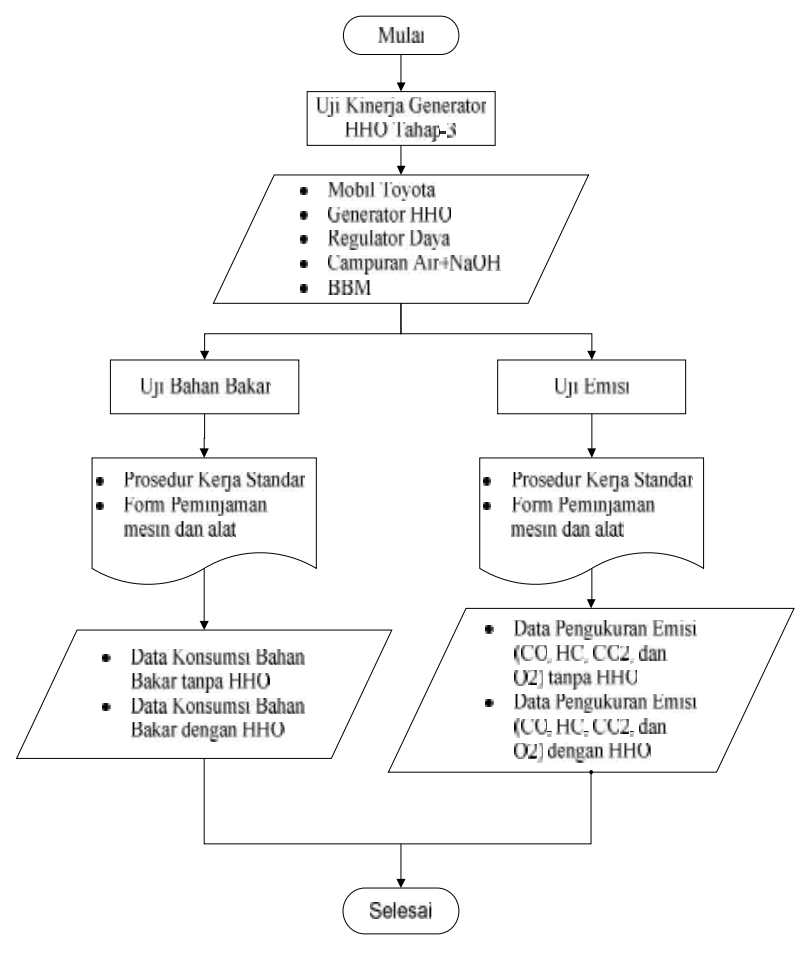

Gambar 5. Flow Chart proses pengujian kinerja generator $\mathrm{HHO}$

\section{HASIL DAN PEMBAHASAN}

Gambar 6 memperlihatkan Purwarupa dari Unit Generator HHO hasil rancangan dengan menyesuaikan tempat yang tersedia pada ruang mesin mobil Kijang. Spesifikasi teknis sebagaimana disajikan pada Tabel 1.
Tabel 1. Spesifikasi teknis generator HHO

\begin{tabular}{lc}
\hline Uraian & Spesifikasi \\
\hline Suplai gas maksimum & $0.95 \mathrm{~L}$ \\
Elektroda (anoda-katoda) & $\mathrm{SS} \mathrm{316 \textrm {L }}$ \\
Tegangan dan arus & $8 \mathrm{~V}-50 \mathrm{~A}$ \\
maksimum & \\
Katalis (2\% volume) & $\mathrm{NaOH}$ \\
Volume kontainer & $1.379 \mathrm{~L}$ \\
Dimensi & $90 \mathrm{~mm} \mathrm{x} \mathrm{216}$ \\
& $\mathrm{mm}$ \\
Berat bersih (tidak termasuk & $3.5 \mathrm{~kg}$ \\
air) & \\
\hline
\end{tabular}

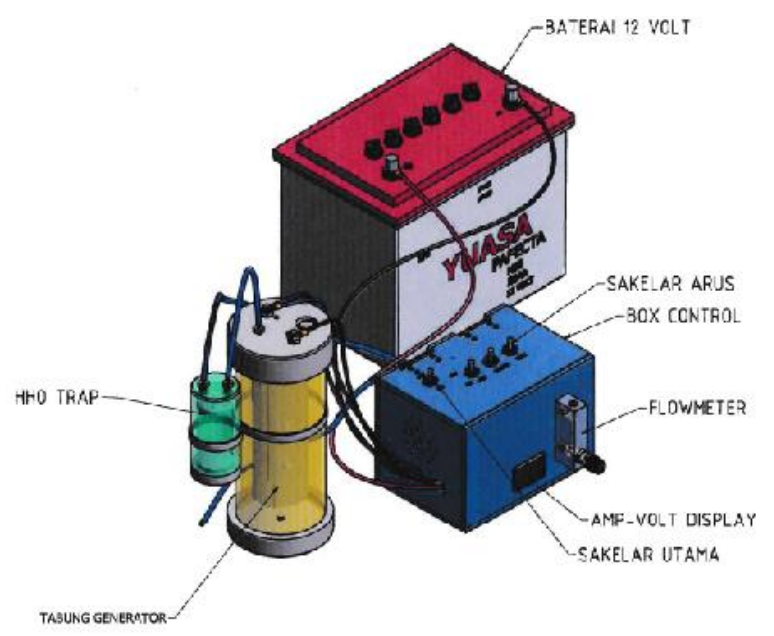

Gambar 6. Skema pemasangan unit generator $\mathrm{HHO}$

Berdasarkan hasil perhitungan dan pengujian diperoleh besarnya konsumsi daya, laju produksi dan performa generator oksihidrogen pada variasi selektor 1 sampai dengan 4 seperti pada Tabel 2 berikut:

Tabel 2. Data perhitungan performa generator HHO

\begin{tabular}{cccccc}
\hline $\begin{array}{c}\text { No } \\
\text { Selector }\end{array}$ & $\begin{array}{c}\text { Arus } \\
(\text { Amp })\end{array}$ & $\begin{array}{c}\text { Tegangan } \\
(\text { Volt })\end{array}$ & $\begin{array}{c}\text { Daya } \\
(\text { watt })\end{array}$ & $\begin{array}{c}\text { Laju Produksi } \\
(\text { LPM })\end{array}$ & COP \\
\hline 1 & 8.3 & 2.91 & 24 & 0.238 & 9.67 \\
2 & 15 & 2.47 & 52 & 0.357 & 6.73 \\
3 & 20.1 & 3.81 & 77 & 0.476 & 6.10 \\
4 & 50 & 8 & 400 & 0.952 & 2.34 \\
\hline
\end{tabular}




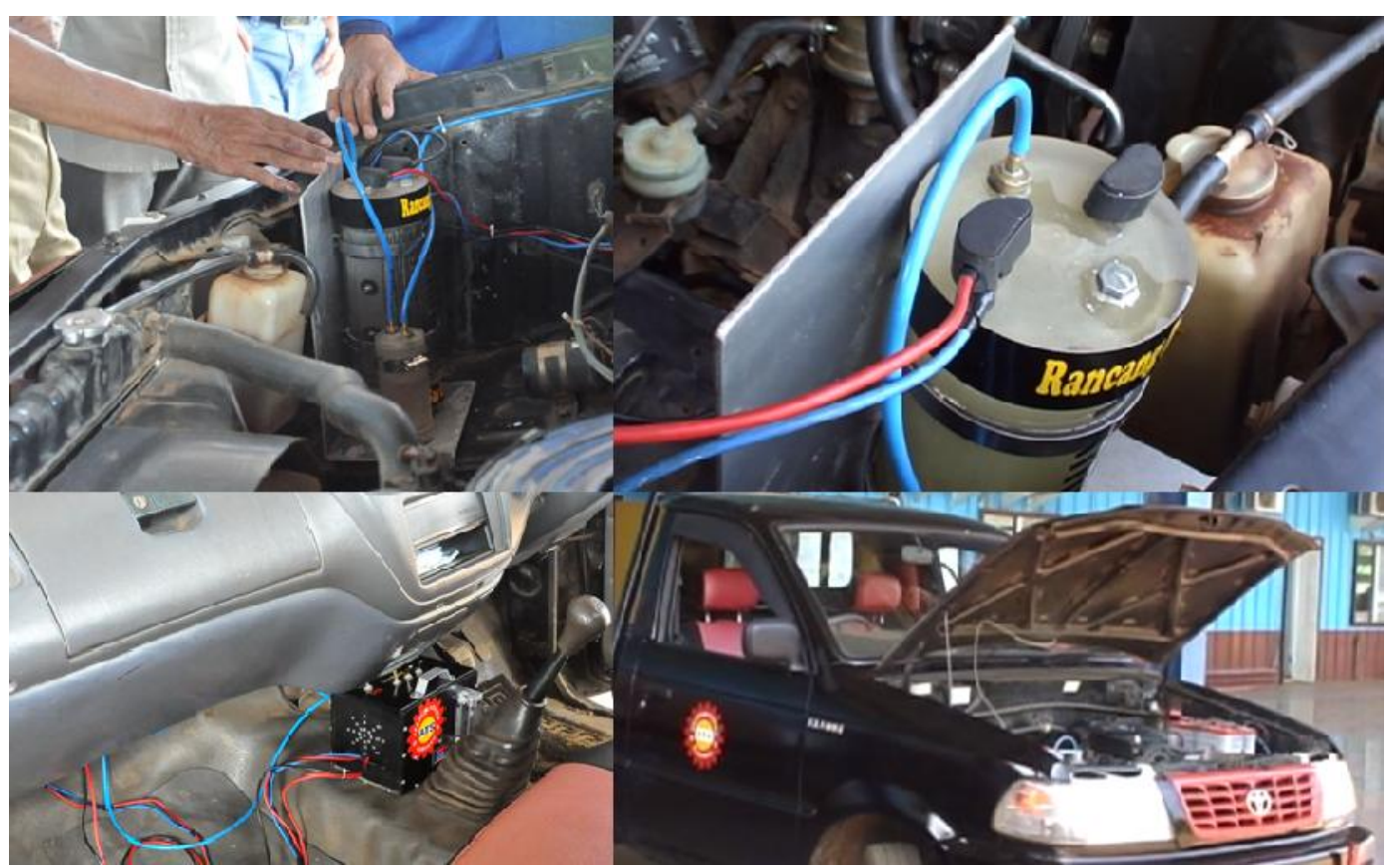

Gambar 7. Proses pemasangan generator pada Mobil Uji

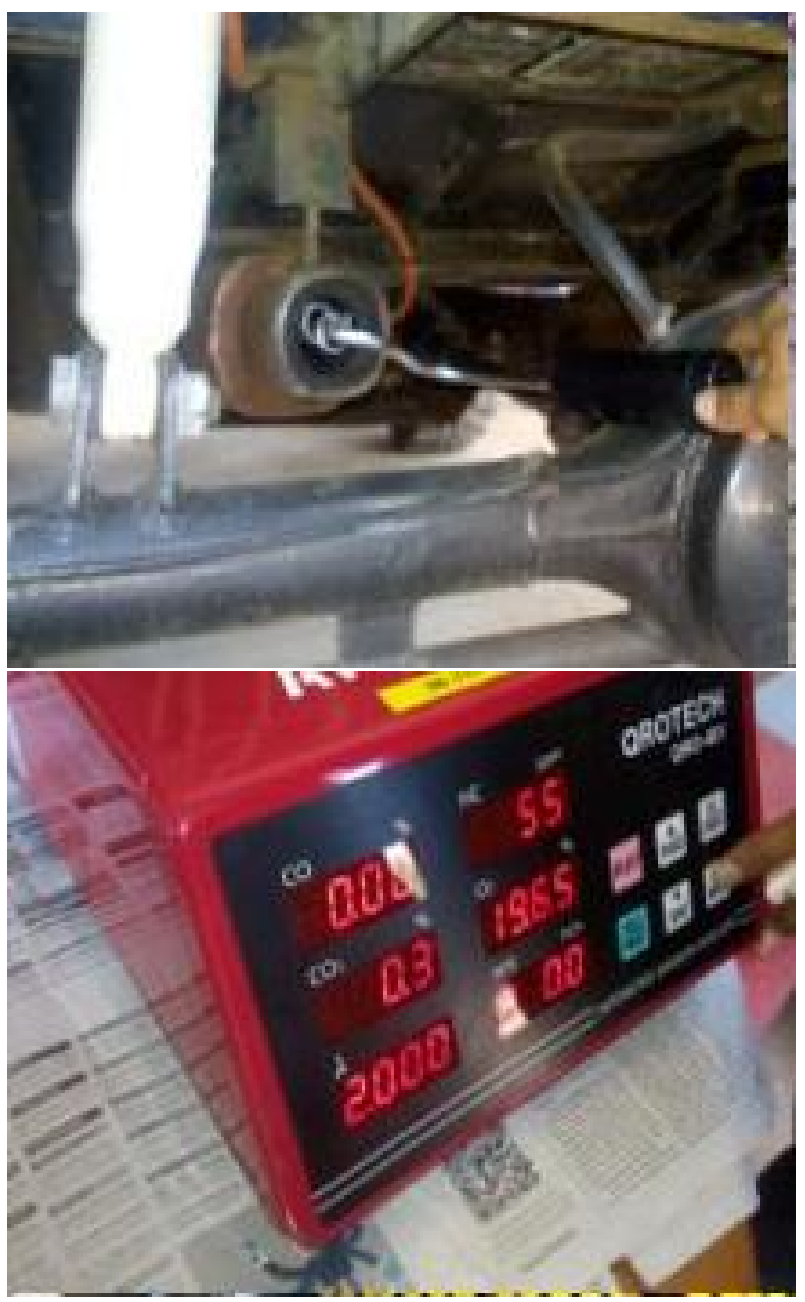

Gambar 8. Proses pengukuran emisi gas buang 


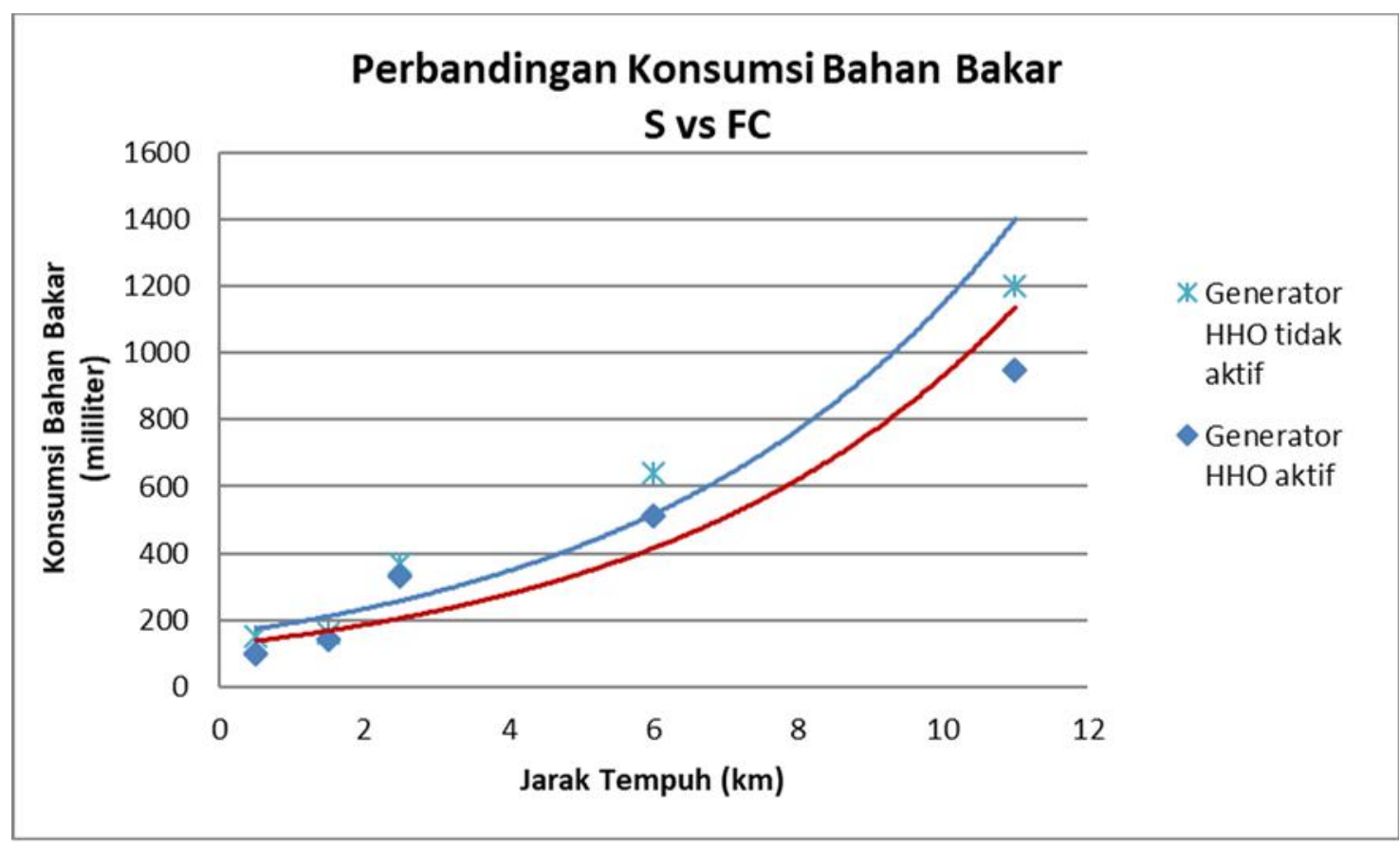

Gambar 9. Grafik perbandingan konsumsi bahan bakar terhadap jarak

Tabel 3. Perbandingan Emisi Gas Buang

\begin{tabular}{clllccc}
\hline \multirow{2}{*}{ No } & \multirow{2}{*}{ Parameter } & \multirow{2}{*}{ Simbol } & Satuan & \multicolumn{2}{c}{ Generator HHO } \\
\cline { 5 - 6 } & & & & Tidak aktif & Aktif \\
\hline 1 & Hidrokarbon & HC & ppm & 257 & 194 \\
2 & Karbonmonoksida & CO & $\%$ vol & 2.5 & 0.05 \\
3 & Karbondioksida & CO2 & \%vol & 10.0 & 6.9 \\
4 & Oksigen & O2 & \% vol & 8.78 & 10.04 \\
\hline
\end{tabular}

Tabel 2 menunjukan bahwa dengan penambahan daya yang digunakan pada generator mengakibatkan kenaikan pula pada produksi gas oksihidrogen. Hal ini terjadi karena sumber daya yang lebih besar dapat menyebabkan proses elektrolisis air dapat berjalan lebih cepat, sehingga produksi hydrogen dan oksigen semakin besar pula hal ini pun sesuai dengan hasil percobaan yang dilakukan oleh Harman dkk. Dari tabel yang sama diperoleh bahwa Performa dari generator mengalami penurunan seiring dengan penambahan daya. Hal ini dapat dijelaskan berkaitan dengan komposisi larutan bahan baku gas HHO. Pada pengujian ini digunakan katalis $2 \%$ dari volume total sehingga diperoleh gas maksimum 0.952 LPM pada temperatur air 70OC dengan konsumsi daya 400W. Kondisi ini sangat riskan karena temperatur air dalam generator sangat tinggi dan jika hal ini berlangsung lama, maka peroduksi gas akan semakin berkurang dan berubah menjadi uap air. Hal sebaliknya jika konsumsi daya dikurangi, akan menurunkan produksi gas namun temperatur air juga semakin turun sehingga campuran uap air dalam gas juga menurun, kemurnian gas HHO semakin baik. 
Gambar 9 memperlihatkan pengaruh konsumsi bahan bakar pada pengoperasian mobil bila menggunakan tambahan gas HHO. Pada jarak pendek, selisih yang dihasilkan masih cukup kecil, namun setelah berlangsung lama dan perjalanan semakin jauh, maka akan lebih besar selisihnya. Hal ini terjadi karena pada jarak pendek ketika proses pembakaran masih di awal-awal, proses pembakaran belum stabil, dan homogenitas campuran udarabahan bakar belum sempurna, sehingga biasanya konsumsi bahan bakar juga masih tinggi dalam menghasilkan daya. Pada jarak jauh, ketika proses pembakaran telah berlangsung lama, maka proses pembakaran juga semakin baik, namun pada kendaraan-kendaraan model lama, akibat sistem pengapian belum sebaik yang model terbaru, maka tetap akan ada bahian bahan bakar yang tidak terbakar dengan sempurnya. Namun dengan penambahan gas HHO yang memiliki sifat mudah terbakar, maka akan menyempurnakan pembakaran dalam ruang bakar sehingga untuk menghasilkan putaran dan daya mesin, konsumsi bahan bakar bensin dapat dikurangi. Demikian halnya dengan Emisi gas buang terutama $\mathrm{CO}$ dan $\mathrm{HC}$ (tabel 3). Munculnya kedua gas berbahaya tersebut akibat tidak sempurnanya proses pembakaran dalam ruang bakar sehingga belum sempat teturai, namun telah ikut keluar bersama gas sisa pembakaran lainnya. Denga adanya tambahan gas HHO, maka proses pembakaran semakin sempurna dan cepat sehingga pembentukan gas $\mathrm{CO}$ dan $\mathrm{HC}$ semakin kecil kemudian ikut keluar bersama gas buang lainnya. Hasil yang diperoleh diatas sejalan dengan hasil penelitian Suyoto (2011) maupun Sudrajat dkk. (2011).

\section{SIMPULAN}

Berdasarkan hasil pengujian dan pembahasan diatas, diperoleh kesimpulan bahwa, dengan penambahan gas HHO pada proses pembakaran, dapat memperbaiki proses pembakaran yang belum sempurna sehingga konsumsi bahan bakar dapat dikurangi hingga 25\%, dan emisi gas buang berbahaya dapat dikurangi seperti CO dan HC dapat diminimalkan. Sedangkan jumlah perolehan gas HHO dari hasil elektrolisis ditentukan oleh konsumsi daya oleh generator serta komposisi katalis dalam air.

\section{UCAPAN TERIMAKASIH}

Kami mengucapkan terimakasih kepada semua pihak yang telah membantu dan memberikan sumbangsihnya terhadap penelitian ini, Terutama kepada Pimpinan Akademi Teknik Soroako, Pimpinan Laboratorium Otomotif Akademi Teknik Soroako, Laboran, dan Mahasiswa yang telah membantu dalam proses pengambilan data-data tak lupa kepada Ketua LPPM Akademi teknik Soroako yang telah memberikan dukungan dana yang tidak sedikit.

\section{DAFTAR RUJUKAN}

Emmanuel Zoulias; Elli Varkaraki et. al. A Review on Water Electrolysis, Centre for Renewable Energy Sources (CRES), Pikermi, Greece.

Harman, H., Arif, E. and Hasan, D., 2015. Pengaruh Penambahan Gas Oksihidrogen Terhadap Unjuk Kerja Motor Bensin Berbahan Bakar Pertamax. DINAMIKA-Jurnal Ilmiah Teknik Mesin, 7(1). 
Hasan, A., 2011. Aplikasi Sistem Fuel Cell Sebagai Energi Ramah Lingkungan di Sektor Transportasi dan Pembangkit. Jurnal Teknologi Lingkungan, 8(3).

Kosar, Murat; Ozdalyan, Bullent; Celik, M.Bahattin. 2011. The Usage of Hydrogen for Improving Emissions and Fuel Consumption in a Small Gasoline Engine. Journal of Thermal Science and Technology, Turkey.

Miranti Wiyandari. 2010. Hubungan Volume Kendaraan terhadap Konsentrasi Polutan NOX di Udara. Skripsi Fakultas Teknik, Program Studi Teknik Lingkungan. Universitas Indonesia, Jakarta.

Nanny Kusminingrum; G. Gunawan. 2008. Polusi Udara akibat aktifitas kendaraan bermotor di jalan perkotaan Jawa dan Bali, Puslitbang Jalan dan Jembatan, Bandung.

Purnomo, Rizki Eko. 2010. Pengujian Performa Generator HHO dengan Air Kemasan dan Pengaruhnya terhadap Engine Generator Set JF154 1500DC. Institut Teknologi 10 Nopember, Surabaya.
Sudrajat, Ajat; Ariffin, Eddy. 2011. Manfaat Gas HHO Untuk Kesejahteraan Masyarakat. Paper Seminar Nasioanal pada Konvensi Nasional BKM-PII, Jakarta.

Sunyoto, Abi. 2011. Oxyhidrogen Hasil Proses Elektrolisa sebagai Aditif Bahan Bakar Motor Bakar. Paper Seminar Nasioanal pada Konvensi Nasional BKM-PII, Jakarta.

Saipul Rijal Juniansyah. 2015. Prototype Hydrogen Fuel Generator Dry Cell Type (Produksi Gas Hidrogen Ditinjau dari Variasi Konsentrasi Elektrolit Asam Klorida dengan Suplai Tegangan Listrik). Laporan Tugas Akhir S1 Terapan, POLITEKNIK NEGERI SRIWIJAYA PALEMBANG

Yilmaz, Ali Can; Uludamar, Erinc; Aydin Kadir. 2010. Effect of hydroxy (HHO) gas addition on performance and exhaust emissions in compression ignition engines. International Journal of Hydrogen Energy.ELSEVIER 